\title{
OPEN Publisher Correction: Deep \\ Machine Learning Techniques for the Detection and Classification of Sperm Whale Bioacoustics
}

Peter C. Bermant, Michael M. Bronstein, Robert J. Wood Shane Gero \& David F. Gruber

Correction to: Scientific Reports https://doi.org/10.1038/s41598-019-48909-4, published online 29 August 2019

In the original version of this Article, the ORCID ID for Shane Gero was omitted.

In addition, Supplementary Information file S6 was omitted from the original version of this Article. These errors have been corrected in the HTML and PDF versions of the Article.

(c) (i) Open Access This article is licensed under a Creative Commons Attribution 4.0 International (c) License, which permits use, sharing, adaptation, distribution and reproduction in any medium or format, as long as you give appropriate credit to the original author(s) and the source, provide a link to the Creative Commons license, and indicate if changes were made. The images or other third party material in this article are included in the article's Creative Commons license, unless indicated otherwise in a credit line to the material. If material is not included in the article's Creative Commons license and your intended use is not permitted by statutory regulation or exceeds the permitted use, you will need to obtain permission directly from the copyright holder. To view a copy of this license, visit http://creativecommons.org/licenses/by/4.0/.

(c) The Author(s) 2019 